\title{
'Assimilação crítica' and research on the periphery
}

\author{
'Assimilação crítica' e pesquisa sobre a periferia \\ Gaylord George Candler ${ }^{1}$ \\ University of North Florida / Master of Public Administration program, United States
}

\begin{abstract}
As one of my two contributions to this discussion, I would like to first comment on the state of affairs regarding the development of "um pensamento nacional autêntico." Specifically, I would like to address the issue not from the perspective of the Brazilian trying to 'critically assimilate' foreign ideas, and so avoid the transplantation of inappropriate scholarship. Rather, I would like to look at it from the other end of this strained intellectual relationship. Much of my research related to Guerreiro Ramos has confirmed the threat that he raised regarding epistemic colonization, unwittingly exercised by a woefully parochial Anglophone scholarly community. The second topic I would like to discuss is a policy area in which Brazilians, especially in my discipline of public administration, might have something to learn from abroad, raised by Guerreiro Ramos himself in his Patologia social do branco brasileiro.
\end{abstract}

Keywords: Epistemology. Social equity. Development assistance.

\section{Resumo}

Como uma das minhas duas contribuições para essa discussão, primeiro, eu gostaria de comentar sobre o estágio atual em relação ao desenvolvimento de "um pensamento nacional autêntico". Especificamente, eu gostaria de abordar a questão não sob a perspectiva do brasileiro tentando 'assimilar criticamente' as ideias estrangeiras, para, assim, evitar o transplante de saber irrelevante. Em vez disso, eu gostaria de observá-lo a partir do outro lado dessa tensa relação intelectual. Grande parte de minha pesquisa relacionada a Guerreiro Ramos confirmou a ameaça apontada por ele acerca da colonização epistêmica, exercida de modo involuntário por uma comunidade acadêmica anglófona terrivelmente paroquial. O segundo tópico que eu gostaria de discutir é uma área política na qual os brasileiros, especialmente na minha disciplina da administração pública, podem ter algo a aprender do exterior, apontada pelo próprio Guerreiro Ramos em seu Patologia social do branco brasileiro.

Palavras-chave: Epistemologia. Equidade social. Raça. Nova gestão público.

Paper submitted on January $26^{\text {th }}, 2015$ and accepted for publication on June $15^{\text {th }}, 2015$.

\section{DOI: http://dx.doi.org/10.1590/1679-395144542}

1 Associate Professor and Director of Master of Public Administration program of University of North Florida. Address: 1 UNF Drive, 32224, Jacksonville - FL, EUA. E-mail: g.candler@unf.edu 


\section{Introduction}

In my native language, Guerreiro Ramos is known almost wholly for his English version of A nova ciência das organizações. Lucia Lippi Oliveira is probably correct, though, that "pode-se apontar como questão central em Guerreiro Ramos a criação de um pensamento nacional autêntico, livre de sociologia alienada entendida como fruto da transplantação e importação de ideias" (OLIVEIRA, 1995, p. 15; AZEVEDO, 2006a, p. 16). As one of my two contributions to this discussion, I would like to first comment on the state of affairs regarding the development of "um pensamento nacional autêntico." Specifically, I would like to address the issue not from the perspective of the Brazilian trying to 'critically assimilate' foreign ideas, and so avoid the transplantation of inappropriate scholarship. Rather, I would like to look at it from the other end of this strained intellectual relationship. While seeking to avoid the naïve, almost ritualistic North American self-criticism while overseas, much of my research related to Guerreiro Ramos has confirmed the threat that he raised regarding epistemic colonization, unwittingly exercised by a woefully parochial Anglophone scholarly community. The second topic I would like to discuss is a policy area in which Brazilians might have something to learn from abroad, raised by Guerreiro Ramos himself in his Patologia social do branco brasileiro.

An important point related to Ramos's critical assimilation was his self-described status as an "inbetweener." As a poor afro-brasileiro, educated in part in the European intellectual tradition, early attracted to the empiricism of the Chicago School of sociology, and who was to subsequently spend the last fifteen years of his academic career in one of the best public administration programs in the United States, Guerreiro Ramos bridged a wide range of intellectual worlds. Given the limits of human reason, it is hardly surprising that the unique insights of this scholar with such an unusual formation were often rejected by those with more conventional backgrounds: elite class origins, and a traditional academic career. This was especially the case in the United States, where in a letter to the publishers of The New Science of Organizations he stated that "as a Brazilian scholar with a European background, I am not so comfortable with the state of social science in America, which in my view is fraught with serious fallacies" (1977). The point here is that critical assimilation is not easy, as it is difficult to challenge a dominant paradigm, whether it be that of the epistemic colonialists who look uncritically to the 'developed' world for policy lessons, or whether it be that of epistemic nationalists who reject lessons that might be gleaned from global best practice (CANDLER and VENTRISS, 2006).

\section{'Assimilação crítica'}

As indicated, Alberto Guerreiro Ramos's A redução sociologica ${ }^{2}$ is widely believed to be his major intellectual contribution, certainly prior to his exile in 1966. The threat of epistemic colonization is not unique to Brazil. I have found evidence of this tension in India, the Philippines, and even two Anglophone countries: Australia and Canada (CANDLER, 2014); while Francisco Salgado has raised similar issues in Ecuador (Salgado 2010). The issue remains relevant in Brazil, as Motta's recent discussion makes clear (2014). In essence, the issue is one of exercising a conscious critical assessment of the otherwise autonomous process of theoretical diffusion.

Post-World War II decolonization saw over 100 new countries arrive on the global scene, and most of these had levels of social and economic development below that of the colonial powers (RAMOS, 1965, p. 14764). Given this "imperativo de acelerar, de modo históricamente positivo, a transformação de contextos subdesenvolvidos" (RAMOS, 1965, p. 119; 1967, p. 40), it was not surprising that the leaders of many of these new societies looked 'north' for policy ideas. Indeed the quote above continues, asserting that this

${ }^{2}$ In this discussion, I am referring to his original, first edition definition of this phrase (see AZEVÊDO and ALBERNAZ, 2006b, p. 504505). 
imperative imposes "ao cientista de países periféricos a exigência de assimilar não mecânicamente o patrimônio científico estrangeiro" (ibid). Ramos, however, became alarmed at what he saw as a tendency to uncritically (or mecânicamente!) adopt lessons from the north.

Ramos argued (from as early as 1951, as detailed by EDISON BARIANI, 2011, p. 65-9) that developing countries should adopt an approach "crítico-assimilativo de experiência estrangeiro" (RAMOS, 1996, p. 74). It is especially worth noting that assimilação crítica was not naively nationalistic. Ramos was not rejecting foreign policy lessons outright. He was certainly both well-informed regarding contemporary thought among development scholars in American public administration (see 1965, p. 96-111; 1966, p. 330-387; 1967, p. 12-22), and even wrote favourably of the ideas of Fred Riggs and others (1966, p. 331-338; 1983, p. 250$255 ; 1983)$. He just insisted on a critical assessment of the likely success of foreign ideas in Brazilian conditions. Indeed, he sought:

Por um lado, integrar a disciplina sociológica nas correntes mais representativas do pensamento universal contemporâneo. Por outro, pretende formular um conjunto de regras metódicas que estimulem a realização de um trabalho sociológico dotado de valor pragmático, quanto ao papel que possa exercer no processo de desenvolvimento nacional. (RAMOS, 1965, p. 53)

So rather than an epistemic nationalism, Guerreiro Ramos wanted Brazil to be part of this global intellectual discourse, at least that part of global intellectual discourse characterized by 'critical assimilation' and so characterized by "pensamento universal contemporâneo" (BARIANI, 2011, p. 105-21). There was reason to think these imported ideas might fail and, half a century later, many of these reasons remain.

\section{Geo-political hegemony}

\section{Epistemic parochialism}

In explaining this otherwise inexplicable tendency for 'developing' country scholars and policy makers to mecanicamente adopt lessons from the 'developed' countries, Guerreiro Ramos especially identifies "o efeito de prestígio" (1965, p. 126-7). Certainly as the 1950s development push was underway, the United States had emerged as the world's economic and military superpower, and so o efeito de prestígio was especially strong. As indicated, my emphasis in these comments is not so much why Brazilians mecanicamente adopted inappropriate lessons, but rather why the Americans offered these.

A first problem with the American, or broader English-speaking hegemonic center of global scholarship in the social sciences, and especially my field of public administration, is that Anglophones are notoriously monolingual, and so unable to directly engage more than a handful of national experiences. A common reason offered (in response to my queries at various conferences) for this Anglophone monolingualism is that everything important is published in English. One might note the irony, in that individuals who can read only English are asserting that nothing of importance is published in other languages. I have offered a more robust refutation of this claim, through analysis of the language of references cited in articles published in major journals of public administration in the United States, France and Brazil. The research is structured around the linguistic concept of diglossia, a situation in which a society includes both a dominant and a subordinate language, with Spanish and Guaraní in Paraguay a classic example. In a situation of diglossia, knowledge of the dominant language confers power.

I found that less than $10 \%$ of articles published in five prestigious American journals of public administration and policy had even one reference in a language other than English. Worse, even when writing about non-English speaking countries, Americans rarely cite the language of the country being studied. In contrast, Brazilian and French scholars, even when writing about their own countries, cited a third 
language, other than English and their own, more than Americans cited a second language when doing comparative research (CANDLER, 2006a, p. 547-51), a situation which is common to Australia and Canada, as well (CANDLER, AZEVEDO and ALBERNAZ, 2010). To put this simply: if French and Brazilian scholars are able to find sources worth citing in languages other than their own and English, it is hard to justify the American inability to cite other than English sources. As a result of this self-induced linguistic diglossia:

The monolingualism that characterizes much of the North American public administration community ironically functions as a sort of reverse diglossia. English is the unquestioned dominant language in both the 'global village' and in international intellectual discourse. Yet rather than a dominant elite, monolingual English speakers are impoverished by their knowledge of only this one language, trapped in an intellectual provincialism of their own making. (CANDLER, 2006a, p. 541)

\section{Mea culpas from the development missionaries}

This diglossia-induced provincialism has long been remarked on by critics. American 'development' scholars of the 1950s through at least the 1970s were characterized by Fred Riggs (1998) as ethnocentric, seeing developing countries as "backward," "traditional," and assuming that American models would help correct this. Implicitly Riggs suggests that American scholars both lacked a global perspective of the American model, and so an understanding of its peculiarities; and failed to engage the local reality so as to better 'critically assimilate' elsewhere that which works in the United States (see also BOYACIGILLER and ADLER, 1991; DWIVEDI, 1999; CANDLER, 2002). Riggs' 1998 comments are especially interesting given his earlier, 1965 reflections in which he laments that American technical advisers were relearning an old lesson, part of which was to "immerse themselves in detail, acquiring all the data they can obtain. [To] master its languages, its history, and its cultural particularities" (1965, p. 78).

This is also evident in 2002 reflections from Frank Sherwood, published in Revista de Administração Pública. While coordinating the University of Southern California technical assistance program to EBAP in the 1950s, he identified language as an early problem: "While it should have been expected that U.S. faculty would have command of Portuguese. Such people could not be found in the U.S." (p. 821). His own Portuguese had improved a couple of years later, but "it was not good enough to engage... in any direct manner" (p. 823). While bemoaning what he perceived as anti-Americanism, he "had the uneasy feeling" that his Brazilian counterpart "did not think that I quite measured up to my responsibility" (p. 821). As well, "the fact that none of us was sufficiently fluent in Portuguese to have a real classroom interaction, meant that we have virtually no association with EBAP students" (p. 827). This was not a model for the critical diffusion of knowledge!

The need for critical assimilation on the part of the deliverers of technical assistance is also evident in an analysis of ninety articles published by Americans in Revista de Serviço Público and Revista de Administração Pública from the mid-1950s through the end of the ditadura. Only four had more than a couple of Brazilian sources, while the large majority neither cited Brazilian sources nor referred to Brazil in the article - no attempt was made to justify the appropriateness to Brazil of the American lesson offered. As I argued earlier:

In essence, the nature of the advice being offered reflected the other end of the 'development assistance' pipeline that Alberto Guerreiro Ramos criticized...in his $A$ redução sociologica. While one way to improve this process was certainly for Brazilians to reject bad ideas, another way to improve the process was for Americans to learn enough about Brazil that they would be less likely to offer bad ideas. (CANDLER, 2006a, p. 545)

A final point regarding the lack of Anglophone 'critical assimilation' of research for Brazilian audiences is that there is relatively little research on Brazil done in English. As an experiment, I entered a number of 
countries into JSTOR, an electronic database of journal articles. In the table below, I list a handful of countries, their population, and the number of hits in JSTOR. ${ }^{3}$

Table 1

Countries in American scholarship

\begin{tabular}{|l|c|c|c|c|c|}
\hline & & \multicolumn{4}{|c|}{ JSTOR category } \\
\hline \multicolumn{1}{|c|}{ Country } & $\begin{array}{c}\text { Population } \\
\text { (millions) }\end{array}$ & $\begin{array}{c}\text { Public policy \& } \\
\text { administration }\end{array}$ & Political science & Economics & Sociology \\
\hline Brazil & 199 & 20 & 275 & 305 & 179 \\
Argentina & 41 & 17 & 152 & 183 & 63 \\
Nigeria & 169 & 29 & 119 & 227 & 160 \\
Indonesia & 247 & 7 & 171 & 288 & 78 \\
France & 66 & 72 & 485 & 684 & 478 \\
Australia & 23 & 106 & 211 & 371 & 321 \\
Denmark & 6 & 35 & 70 & 144 & 153 \\
\hline
\end{tabular}

Source: Elaborated by the author.

Note that Brazil is under-represented: Argentina, with perhaps $20 \%$ of Brazil's population, gets (sociology excepted) half to nearly equal the attention Brazil receives. Indonesia is even less studied than Brazil. France, with $1 / 3^{\text {rd }}$ the population of Brazil, gets 2-3 times more attention, despite the language barrier. Even Australia and Denmark, with a fraction of Brazil's population, receive relatively more (and in a couple of instances, absolutely more) attention. So my point is that Brazil is under-represented, and so the Anglophone researcher seeking to engage the country has little to work with. For some other major countries the lack of Anglophone engagement is even more marked, as the Indonesian data illustrates.

\section{Two contemporary applications of assimilação crítica}

\section{The odd case of the Nova Gestão Público ${ }^{4}$}

Unfortunately bad (or at least particularistic, rather than universal) American ideas abound, especially given the atypical nature of American society. This certainly applies to the 'New Public Management' movement. In broad terms, the particularistic, culturally-specific nature of the intellectual home of this approach is reflected in Table 2.

${ }^{3}$ I searched for these countries in the abstract of articles, restricted the results to English language.

4 It is worth noting that this is often translated as "nova administração pública." While 'management' and 'administration' are synonyms, within American public administration the New Public Administration refers to a 1960s-inspired movement that emphasized ethics, citizenship, civic participation, and especially what Guerreiro Ramos called sociologia em mangas de camisa (MARINI, 1971). 
Table 2

Some market individualism indicators

\begin{tabular}{|c|c|c|c|c|c|c|}
\hline & $\begin{array}{l}\text { Hofstede's } \\
\text { Individualism }\end{array}$ & $\begin{array}{l}\text { Economic } \\
\text { freedom }\end{array}$ & $\begin{array}{c}\text { Ease of } \\
\text { doing } \\
\text { business }\end{array}$ & $\begin{array}{l}\text { Size of } \\
\text { govt }\end{array}$ & $\begin{array}{l}\text { Govt final } \\
\text { consumption }\end{array}$ & $\begin{array}{c}\text { Govt } \\
\text { regulation }\end{array}$ \\
\hline \multicolumn{7}{|l|}{ G7+2 } \\
\hline US & 91 & 7.96 & 3 & 7.13 & 16 & 7.89 \\
\hline Australia & 90 & 7.90 & 9 & 6.80 & 19 & 8.24 \\
\hline Canada & 80 & 7.95 & 7 & 6.54 & 19 & 8.30 \\
\hline France & 71 & 7.32 & 31 & 5.43 & 23 & 7.01 \\
\hline Germany & 67 & 7.46 & 20 & 5.64 & 18 & 6.25 \\
\hline Italy & 76 & 6.90 & 53 & 5.71 & 20 & 6.54 \\
\hline Japan & 46 & 7.46 & 12 & 6.18 & 18 & 7.73 \\
\hline Sweden & 71 & 7.28 & 14 & 3.61 & 26 & 7.27 \\
\hline UK & 89 & 7.81 & 6 & 6.02 & 22 & 7.89 \\
\hline \multicolumn{7}{|l|}{ BRICs+1 } \\
\hline Brazil & 38 & 6.18 & 122 & 6.39 & 20 & 5.01 \\
\hline China & 20 & 6.65 & 83 & 4.51 & 14 & 5.62 \\
\hline India & 48 & 6.51 & 120 & 6.84 & 11 & 6.31 \\
\hline Russia & 39 & 6.62 & 106 & 7.27 & 19 & 5.91 \\
\hline Indonesia & 14 & 6.44 & 123 & 7.11 & 8 & 6.08 \\
\hline \multicolumn{7}{|l|}{ Others } \\
\hline Pakistan & 5.84 & 14 & 67 & 7.71 & 9 & 6.29 \\
\hline Nigeria & 6.06 & 20 & 108 & 5.89 & -- & 7.21 \\
\hline Vietnam & 6.15 & 20 & 91 & 6.27 & 6 & 6.34 \\
\hline Venezuela & 4.32 & 12 & 172 & 5.09 & 10 & 4.82 \\
\hline
\end{tabular}

Sources: Individualism: Hofstede (2010). Economic freedom: Heritage Foundation (2008). The data is on a 1-10 scale, with 10 equal to more economic freedom (i.e. less government 'meddling'). The data are for 2008. Ease of doing business: World Bank (2008). A ranking (1 to 178). Size of government and government regulation: Fraser Institute (2008). Economic Freedom of the World Report. These are ratings of economic freedom, on a 1-10 scale, with 10 being perfect economic freedom. Government final consumption: World Development Report. The figures are for final government consumption, as \% GDP, 2008 data.

As the table shows, the United States (and the Anglophone world in general, see PAULA, 2007, p. 27-45) is atypically individualistic. Note, too, that while the US (and Anglophone model) has been successful, as a number of Anglophone countries are among the most successful in terms of social and economic outcomes; the Anglophone, individualistic model is not the only route to success, as (among the few examples in Table 1) the French and Swedish models show. These countries have managed to be among the world's wealthiest, despite a more collectivist national culture. This is also reflected in Table 3, which presents a range of outcome indicators for the sample in Table 2. US success is again evident, especially in income per capita figures. However these average figures mask the rich world's highest inequality. This inequality is likely also reflected in America's lowest rich world life expectancy, despite this wealth. If the goal of society is to 
"promote the general welfare," as stated in the Preamble to the US Constitution, then the American model, again, is less than ideal.

Table 3

Some outcome indicators

\begin{tabular}{|c|c|c|c|c|c|}
\hline & HDI & Income & Inequality & Life Expectancy & Life satisfaction \\
\hline \multicolumn{6}{|l|}{ G7+ } \\
\hline US & .902 & 47,094 & 40.8 & 79.6 & 7.9 \\
\hline Australia & .937 & 38,692 & 35.2 & 81.9 & 7.9 \\
\hline Canada & .888 & 38,668 & 32.6 & 81.0 & 8.0 \\
\hline France & .872 & 34,341 & 32.7 & 81.6 & 7.1 \\
\hline Germany & .885 & 35,308 & 28.3 & 80.2 & 7.2 \\
\hline Italy & .854 & 29,619 & 36.0 & 81.4 & 6.7 \\
\hline Japan & .884 & 34,692 & 24.9 & 83.2 & 6.8 \\
\hline Sweden & .885 & 36,936 & 25.0 & 81.3 & 7.9 \\
\hline UK & .849 & 35,087 & 36.0 & 79.8 & 7.4 \\
\hline \multicolumn{6}{|l|}{ BRICs } \\
\hline Brazil & .699 & 10,607 & 55.0 & 72.9 & 7.6 \\
\hline China & .663 & 7258 & 41.5 & 73.5 & 6.4 \\
\hline India & .519 & 3337 & 36.8 & 64.4 & 5.5 \\
\hline Indonesia & .600 & 3957 & 37.6 & 71.5 & 5.7 \\
\hline South Africa & .597 & 9812 & 57.8 & 52.0 & 5.0 \\
\hline Russia & .719 & 15,258 & 43.7 & 67.2 & 5.9 \\
\hline \multicolumn{6}{|l|}{ Others } \\
\hline Pakistan & .490 & 2678 & 31.2 & 67.2 & 5.4 \\
\hline Nigeria & .423 & 2156 & 42.9 & 48.4 & 3.8 \\
\hline Vietnam & .572 & 2995 & 37.8 & 74.9 & 5.4 \\
\hline Venezuela & .696 & 11,846 & 43.4 & 74.2 & 7.8 \\
\hline
\end{tabular}

Sources: Human Development Report 2010. All indicators are 2010 unless otherwise indicated. The HDI is a 0-1 scale, with higher scores better. Income is Gross National Income per capita at purchasing power parity, 2008. Inequality is the Gini Coefficient, a 0-100 scale with higher scores indicating more inequality. Life expectancy: at birth, 2010. Overall life satisfaction is a 0-10 scale, with 10 more satisfied (2006-2009).

It is worth noting, though, that there is still a case to be made for the logic of nova gestão público inspired reforms. Too often both politics and scholarship become rigidly ideological, rather than a pragmatic, multidimensional approach to human governance. Guerreiro Ramos himself, in The New Science, recognized a role for markets (his economic 'setting', 1981, p. 129-31), though at times his enthusiasm seems forced (p. $131)$ !

As suggested in Table 2, in US (and other Anglophone) policy debates a problem with the continued advocacy of market-inspired nova gestão público reforms is that these are already the rich world's most 
'economic' (in Guerreiro Ramos's terms) societies. There is no model to which they can point, further along the 'less government' continuum (as suggested in Figure 1 below). Indeed Somalia (as suggested in a humorous YouTube video, see "Regulation Vacation Celebration") is the next existing model. Granted, there is a long distance between America and Somalia, and it may well be that Ayn Rand's libertarian utopia lies between the US and Somalia. But there is no empirical evidence supporting this assertion, indeed there is considerable evidence that the US has dangerously deregulated (see the blue ribbon group who support this view, cited by CANDLER, 2010, p. 328).

Figure 1

Models of governance in terms of government v. markets

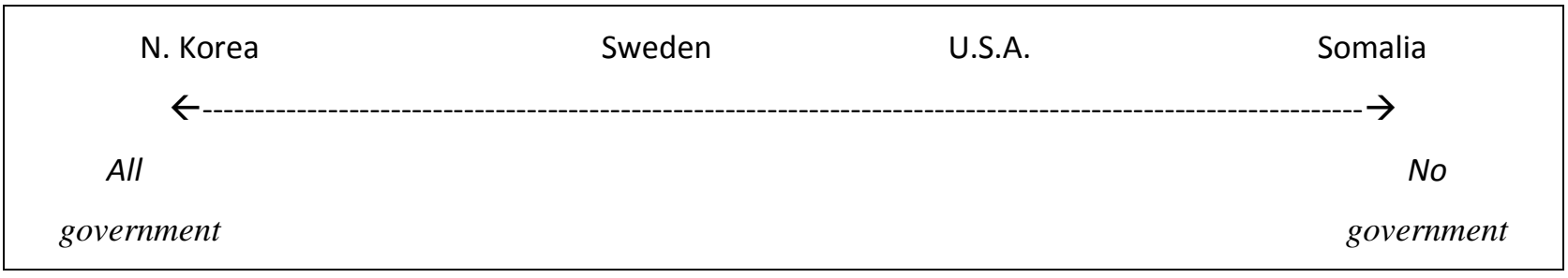

Source: Elaborated by the author.

Put briefly: the US is one of the least governed modern societies in the world today, and so there is great risk in calls to expand Ramos's economic setting even further. Given its income Brazil, on the other hand, has relatively more government and regulation than is the norm. Coupled with at best mixed levels of government efficiency and accountability, one can at least make the case for some expansion of the economic setting, on the grounds of 'pragmatismo por necessidade' (ALMEIDA, 1996; BRESSER PEREIRA, 1998). Still, the culturally specific, ideological foundation of the nova gestão público calls for careful assimilação crítica.

\section{Patologia Social do Branco Brasileiro}

Of the major intellectual contributions made by Guerreiro Ramos, his work on what Americans in the field of public administration would call 'social equity,' is probably the least remembered. ${ }^{5}$ A common cliché about Brazil is that it is a racial democracy, with carnaval the mythologized metaphor for this. In the myth of carnaval, people of all races mingle harmoniously in the streets (GUERREIRO RAMOS, 1999; SANTOS, 1998, p. 119-122). Regardless of the truth of this claim, in the other 51 weeks of the year the reality is different. Critical assimilation of the experience of North America's former slave-owning society may help to illustrate. Even though afro-brasileiros constitute a larger part of Brazil's population than Afro-Americans do the United States; afro-brasileiros are less represented in economic and political circles than are AfroAmericans. As in America, afro-brasileiros also fare much worse on a range of socio-economic indicators (HASENBALG, 1995; NASCIMENTO, 2003, p. 113-56; THE ECONOMIST, 2012).

As a result of this correlation between race and socio-economic outcomes, in the 1950s Guerreiro Ramos's Patologia Social do Branco Brasileiro forcefully argued that Brazil did have a racial problem, and rather than a problem of Afro-Brazilians, the problem was in large part one of discrimination against AfroBrazilians, with this especially reflected in racial self-alienation. As he put it

${ }^{5}$ As an aside, an oddity that I have noticed in my own research is that he seemed to have dropped this line of research himself. In $A$ nova ciência, for instance, despite the strong emphasis on substantive concerns (1981, p. 102-120), despite the recognition of race (from the 1940s) and social class (from the 1950s) in his initial discipline of sociology (CANDLER, 2006b, p. 4), and despite some initial interest in the topic of racial inequity in American public administration in the 1970s (ibid), in A nova ciência Ramos makes no reference to race, or especially to his own pioneering research on this topic. 
A minha tese é a que, nas presentes condições da sociedade brasileira, existe uma patologia social do "branco" brasileiro e, particularmente, do "branco" do Norte e Nordeste... Esta patologia consiste em que, no Brasil, principalmente naquelas regiões, as pessoas de pigmentação mais claro tendem a manifestar, em sua auto-avaliação estética, um protesto contra si próprias, contra a sua condição étnica objetiva. E é êste disequilíbrio na autoestimação, verdadeiramente coletivo no Brasil, que considero patológico. (1955, p. 9-10; see also NASCIMENTO, 1976, p. 25)

Economic disadvantage, independent of race, was also a major contributor to the problem. He elaborated later on this, contending that "o problem efectivo do negro no Brasil é essencialmente psicológico e secundariamente econômico" (1954, p. 157). Indeed for Ramos, the economic problem was not a racial problem, because as a majority in Brazilians are of African descent, this poverty was a Brazilian problem, not a racial one. Instead, "a condição do negro no Brasil só é sociologicamente problemática em decorrência da alienação estética do próprio negro e da hipercorreção estética do branco brasileiro, ávido de identificação com o europeu" (1954, p. 157). So rather than a problem of race, it was a problem of racism.

Despite this, twenty years ago Hasenbalg noted that although more than half of Brazilians favored explicit class-based action to redress class-based social inequity, fewer than $10 \%$ approved similar racially-based action to redress race-based inequity $(1995$, p. 367-8). This is also reflected in continued opposition to racial quotas or other forms of 'affirmative action' meant to offset the discrimination, economic inequality, and psychological impediments identified by Guerreiro Ramos half a century ago.

This inattention to race in Brazilian public administration scholarship is especially significant given how race has been overlooked partly because "the existence of racism is repeatedly denied and confused with forms of class discrimination" (GUIMARÃES, 2001, see also NASCIMENTO, 2003, p. 46-7). Yet even though the country's yawning racial disparities, among the most rigid in the world (RIBEIRO and SCANLON, 2001), have been excused as a social class problem, the public administration discipline has failed to address issues of social class. My own research on this topic has shown that, at least as reflected in RAP and RSP, attention to social equity (whether race, class or gender) is weaker even than among similar scholars in Canada, Australia, and especially the United States. Indeed, through 2000, Revista de Administração Pública had yet to publish an article that addressed issues of race (OLDFIELD, CANDLER and JOHNSON, 2006, p. 160).

\section{Towards 'assimilação crítica'}

An implication of the discussion above is that Brazilians should reduce the scholarly hegemony exercised by the Anglophone literature by drawing on, and especially contributing to, the correntes mais representativas do pensamento universal contemporâneo that Guerreiro Ramos referred to. Granted, language remains a challenge here. ${ }^{6}$ However some steps can be taken. The availability in Brazilian research of abstracts in French, Spanish and/or English helps make it possible for those who seek to be contemporary 'universalistic' scholars elsewhere to at least be aware of relevant Brazilian research. Scielo might also make it a point to gain access to journals from outside 'the core'. Within public administration, for instance, the Indian Journal of Public Administration and Philippine Journal of Public Administration, published in English, have to be more relevant to Brazilian researchers (CANDLER, 2014) than is the inclusion in this otherwise excellent database of yet another American journal.

The central point of this discussion has been that Alberto Guerreiro Ramos held justifiable concerns about the appropriateness of much of the American development experience, especially as understood by American technical assistance advisers themselves. Even among many of these American advisers, the limitations of

\footnotetext{
${ }^{6}$ Not least as evidenced by my inability to write for publication in Portuguese!
} 
their approach has been long understood, but not acted on. It is also worth noting that during much of this period of US technical assistance to academic public administration in Brazil, a military government was in place. Elio Gaspari's four volume history of the ditadura concludes that though the US was not responsible for the 1964 coup it knew it was likely to occur (GASPARI, 2002a, p. 62-4), encouraged it rather than tried to prevent it, and supported the subsequent military government ( 2002b, p. 97-116, p. 283-286, 329-34; 2003 , p. 542-546), even though this regime practiced "press censorship and torture of political prisoners" (2002a, p. 36; 2004, p. 331-337). Despite these gross human rights abuses, American public administrators continued to work on technical assistance projects in the country.

Despite the occasional odd claim that US technical assistance during this period sought to export an ideology of Americanization, a component of which was democracy (ALCADIPANI and CALDAS, 2012, p. 40), this coexistence of American-supported dictatorship, and technical assistance in public administration, was not unique to Brazil. Seitz, for instance, noted that earlier technical advisers in Iran lacked "adequate training in Iranian culture, language, history, economics or politics before coming to Iran" (1980a, p. 411), and worked with a regime also characterized by gross human rights abuses, especially by SAVAK, a secret police force

\footnotetext{
...known for its brutality. With hindsight it is now clear that the Americans' general ignorance of Iran when they initiated major assistance in public administration, made it most likely that the assistance would not be successful. (1980b, p. 441)
}

So the issue is more serious even than development 'assistance' failing to help. This value-neutral, poorly informed development assistance no doubt occasionally did harm to those it aimed to help. Worse for Americans, their own country has often been harmed. Leaving aside the legacy of popular ill-will as a result of American support for myriad dictatorships, this (especially monolingual) parochialism has been cited as a major reason both for the failure to stop the mass murders of 11 September 2001 (9-11 COMMISSION REPORT, 2004, p. 77); while the billions subsequently wasted in Iraqi reconstruction has been blamed in part on "poor American knowledge about what Iraq needed," not least because "the United States failed to consult sufficiently with Iraqi authorities when planning the reconstruction program" (BROWN, 2013, p. 11).

Given the often incompetent, even morally vacuous, one-way nature of the 'development assistance' experience of the 1950s and 1960s, Alberto Guerreiro Ramos's A Redução Sociológica represented a rare, and fascinating example of a robust critique from the south of the development experience of the period. It sought to decolonize the process, and empower Brazilians in the face of the contemporary development challenge. Happily for Brazil, the era of 'technical assistance' is over, as Brazil now funds its own programs giving Brazilians exposure to international experience, and so Brazilians are able to exercise more control over this information exchange, not least in pro-actively seeking out lessons from societies, rather than passively learning only from those countries willing to fund 'technical assistance'.

The issue now is whether the American experience is worth engaging. Despite the impact of parochialism on the quality of this research, it most certainly is, as the quantity and breadth of this research is extensive. Care is required, however, and with vigorous application of Guerreiro Ramos's assimilação critica there is much to learn. At the margin, though, there is far more for Brazil to gain from a young scholar spending a sandwich year in India, or Australia, or France, or the Philippines, or Canada, South Africa, or any of a number of other countries. 


\section{References}

ALCADIPANI, R.; CALDAS, M. C. Americanizing Brazilian Management. Critical Perspectives on International Business, v. 8, n. 1, p. 37-55, 2012.

ALMEIDA, M. H. T. de. Pragmatism por Necessidade: Os Rumos da Reforma Econômica no Brasil. Dados, v. 39, n. 2, p. 213-234, 1996.

AZEVEDO, A. A Sociologia Anthropocêntrica de Alberto Guerreiro Ramos. (Doctoral dissertation) Universidade Federal de Santa Catarina, Florianópolis, 2006a.

AZEVEDO, A.; ALBERNAZ, R. O. Alberto Guerreiro Ramos's Anthropological Approach to the Social Sciences: The Parenthetical Man. Administrative Theory \& Praxis, v. 28, n. 4, p. 501-521, 2006b.

BARIANI, E. Guerreiro Ramos e a redenção sociológica: Capitalismo e sociologic no Brasil. São Paulo: Editor UNESP, 2011.

BOYACIGILLER, N.; ADLER, N. The parochial dinosaur: Organization science in a global context. Academy of Management Review, v. 16, p. 262-290, 1991.

BRESSER PEREIRA, L. C. Reforma do Estado para a Cidadania. São Paulo: ENAP, 1998.

BROWN, S. Learning from Iraq: A Final report from the Special Inspector General for Iraq Reconstruction. Washington: Special Inspector General for Iraqi Reconstruction, 2013. Available at: <http://cybercemetery.unt.edu/archive/sigir/20131001080029/http://www.sigir.mil/files/learningfromiraq/Report_-

_March_2013.pdf>. Access on: 2 February 2015.

CANDLER, G. G. Particularism versus universalism in the Brazilian public administration literature. Public Administration Review, v. 62, p. 298-306, 2002.

CANDLER, G. G. Linguistic diglossia and parochialism in American public administration: The missing half of Guerreiro Ramos’s Redução Sociológica. Administrative Theory \& Praxis, v. 28, n. 4, p. 540-61, $2006 a$.

CANDLER, G. G. Further evidence on the social equity record of academic public administration. Denver, Colorado: American Society for Public Administration, 2 April 2006b. Available at: <http://www.unf.edu/ g.candler/articles/Candler-ASPA06.pdf>. Access on: 2 February 2015.

CANDLER, G. G. Toward a Public-Spirited Public Management Economics. Administrative Theory \& Praxis, v. 32, n. 3 , p. $327-347,2010$.

CANDLER, G. G. The study of public administration in India, the Philippines, Canada and Australia: the universal struggle against epistemic colonization, and toward critical assimilation. Rev. Adm. Pública, v. 48, n. 5, p. 1073-1092, 2014.

CANDleR, G. G.; AZEVEDO, A.; AlBERnAZ, R. O. Towards Global Scholarship in Public Affairs. Public Administration, v. 88, n. 3, p. 836-850, 2010.

CANDLER, G. G.; VENTRISS, C. Symposium - The Destiny of Theory: Beyond the New Science of Organizations. Administrative Theory \& Praxis, v. 28, n. 4, p. 495-500, 2006.

DWIVEDI, O. P. Development administration: Its heritage, culture and challenges. Canadian Public Administration, v. 33, p. 91-98, 1990.

GASPARI, E. A ditadura envergonhada. São Paulo: Editora Schwarz, 2002a.

GASPARI, E. A ditadura escancarada. São Paulo: Editora Schwarz, 2002b.

GASPARI, E. A ditadura derrotada. São Paulo: Editora Schwarz, 2003. 
GASPARI, E. A ditadura encurralada. São Paulo: Editora Schwarz, 2004.

GUIMARÃES, A. S. Race, class and color. NACLA Report on the Americas, v. 34, n. 6, p. 38-41, 2001.

HASENBALG, C. Entre o Mito e os fatos: Racismo e Relações Raciais no Brasil. Dados, v. 38, n. 2, p. 355-374, 1995.

MARINI, F. (Ed.). Toward a New Public Administration: The Minnowbrook Perspective. New York: Chandler, 1971.

MOTTA, P. R. Revisitando a controvérsia sobre a transmissibilidade intercultural do conhecimento administrative. Cad. EBAPE.BR, v. 12, n. 3, p. 553-572, 2014.

NASCIMENTO, A. Abdias do Nascimento. In: CAVAlCANTI, P. C. U.; RAMOS, J. Memórias do exílio. Lisboa: Editoria Arcádia, 1976.

NASCIMENTO, E. O Sortilégio de Cor. São Paulo: Selo Negro, 2003.

OLDFIELD, K.; CANDLER, G. G.; JOHNSON, R. Social Class, Sexual Orientation, and Toward Proactive Social Equity Scholarship. American review of Public Administration, v. 36, n. 2, p. 156-172, 2006.

OLIVIERA, L. L. A Sociologia do Guerreiro. Rio de Janeiro: Editora UFRJ, 1995.

PAULA, A. P. P. de. Por uma nova gestão pública. Rio de Janeiro: Editora FGV, 2007.

RAMOS, A. G. A sociologia de Max Weber (sua importância para a teoria e a prática da administração). Revista de Serviço Público, v. 13, n. 2/3, 1946.

RAMOS, A. G. Patologia social do branco brasileiro. Rio de Janeiro: Jornal do Commercio, 1955.

RAMOS, A. G. Introdução Crítica à Sociologia Brasileira. Rio de Janeiro: Editora UFRJ, 1957.

RAMOS, A. G. A redução sociológica. Rio de Janeiro: ISEB, 1965.

RAMOS, A. G. A modernização em nova perspectiva. Rev. Adm. Pública, v. 1, n. 2, p. 7-44, 1967.

RAMOS, A. G. Letter to R. Davidson. Toronto: University of Toronto Press, October 10, 1977.

RAMOS, A. G. The New Science of Organizations. Toronto: University of Toronto Press, 1981.

RAMOS, A. G. Administração e context brasileiro. Rio de Janeiro: Editora FGV, 1983.

RAMOS, A. G. A redução sociológica. Rio de Janeiro: Editora UFRJ, 1996.

RAMOS, E. G. Gabriela Cravo e Canela: Jorge Amado and the myth of the sexual mulata in Brazilian culture. In: OKPEWHO, I.; DAVIS, C.; MAZRUI, A. (Eds.). The African Diaspora: African origins and New World identities. Bloomington: Indiana University Press, 1999. 227-33p.

RIBEIRO, C. A. C.; SCANLON, M. C. Mobilidade de Classe no Brazil em Pespectiva Comparada. Dados, v. 44, n. 1, p. 53-96, 2001.

RIGGS, F. Relearning an Old Lesson: The Political Context of Development Administration. Public Administration Review, v. 25, n. 1, p. 70-79, 1965.

RIGGS, F. Public administration in America: Why our uniqueness is exceptional and important. Public Administration Review, v. 58, p. 22-31, 1998.

SALGADO, F. Sumuq Kawsay: the birth of a notion? Cad. EBAPE.BR, v. 8, n. 2, p. 199-208, 2010. 
SANTOS, J. T. dos. A mixed-race nation. In: KRAAY, H. (Ed.). Afro-Brazilian Culture and Politics. Armonck, NY: M.E. Sharpe, 1998. 117-33p.

SEITZ, J. The failure of U.S. technical assistance in public administration: The Iranian case. Public Administration Review, v. 40, p. 407-13, 1980a.

SEITZ, J. Iran and the future of U.S. technical assistance: Some afterthoughts. Public Administration Review, v. 40, p. 432-3, 1980 b.

SHERWOOD, F. Some notes and memories on EBAP in its earlier days. Rev. Adm. Pública, v. 36, n. 5, p. 813-27, 2002.

THE ECONOMIST. Race in Brazil: Affirming a divide. 28 January, 2012. Available at: <http://www.economist.com/node/21543494>. Access on: February 2015.

UNITED NATIONS DEVELOPMENT PROGRAM. Human Development Report 2010, New York: United Nations, 2010 .

UNITED STATES. The 9-11 Commission Report. Washington, 2004. Available at: <http://govinfo.library.unt.edu/911/report/911Report.pdf>. Access on: 2 February 2015.

YOUTUBE. Regulation Vacation Celebration. Available at: <https://www.youtube.com/watch?v=7QDv4sYwjO0>. Access on: 2 February 2015. 